\title{
IMPROVING KNOWLEDGE AND PERSONAL HYGIENE IN FEMALE ADOLESCENTS DURING MENSTRUAL PERIOD USING BOOKLET : A SYSTEMATIC REVIEW
}

\author{
Anisya Fajar Rahmawati'), Maulida Rahmawati Emha²), Arif Tirtana')
}

Study Program of Nursing, School of Health Sciences Madani Yogyakarta

\begin{abstract}
Background: Adolescent is an essential period where females are preparing and adjusting themselves to manage their menstrual bleeding in safe and clean way. However, most adolescent girls (girls with age ranges of 10 to 19 years old) enter to their puberty stage (maturity) without preparing themselves due to the shortage of adequate information. This study aimed to investigate the effectiveness of booklet media to improve knowledge and personal hygiene in female adolescents during menstruation.

Subjects and Method: A systematic review was conducted using the PubMed, Google Schoolar, and Researchgate databases and the following search criteria: "health education" and "booklet" and "menstrual hygiene" and "knowledge" and "behavior". Articles published from 2010 to 2020 were collected for this study.

Results: 7 articles was systematically reviewed. This study showed that health education using booklet media has an effect to elevate knowledge and personal hygiene during menstrual period in female adolescents. Booklet has the following advantages: (1) simple and self-study information, (2) attractive, (3) understandable, (4) easy to carry), and (5) applicable.

Conclusion: Health education using booklet media on menstrual hygiene is effective to improve knowledge in maintain menstrual hygiene in female adolescents.

Keywords: health education, booklet media, menstrual hygiene, knowledge, behavior

Correspondence :

Anisya Fajar Rahmawati. Study Program of Nursing, School of Health Sciences Madani Yogyakarta. Jl. Karanggayam, Bantul 55792, Yogyakarta, Indonesia. Email: anisyafajar25@gmail.com. Mobile: 085715840985.
\end{abstract}

The $8^{\text {th }}$ International Conference on Public Health Solo, Indonesia, November 17-18, 2021 | 83 https://doi.org/10.26911/AB.Promotion.ICPH.08.2021.15 